\title{
Growing through Cities in Developing Countries
}

This paper examines the effects of urbanization on development and growth. It begins with a labor market perspective and emphasizes the importance of agglomeration economies, both static and dynamic. It then argues that more productive jobs in cities do not exist in a void and underscores the importance of job and firm dynamics. In turn, these dynamics are shaped by the broader characteristics of urban systems. A number of conclusions are drawn. First, agglomeration effects are quantitatively important and pervasive. Second, the productive advantage of large cities is constantly eroded and must be sustained by new job creation and innovation. Third, this process of creative destruction in cities, which is fundamental for aggregate growth, is determined in part by the characteristics of urban systems and broader institutional features. We highlight important differences between developing countries and more advanced economies. A major challenge for developing countries is to reinforce the role of their urban systems as drivers of economic growth. Cities and development, Local labor markets, Jobs and firm dynamics, Urban systems. JEL codes: j24, o18, r23

Urbanization and development are tightly linked. The strong positive correlation between the rate of urbanization of a country and its per capita income has been repeatedly documented (see, for instance, World Bank 2009; Henderson 2010; Henderson 2002). Much of the causation goes from economic growth to increased urbanization. As countries grow, they undergo structural change, and labor is reallocated from rural agriculture to urban manufacturing and services (Michaels, Rauch, and Redding 2012). ${ }^{1}$ The traditional policy focus is to ensure that this reallocation occurs at the 'right time' and that the distribution of population across cities is 'balanced'. Urbanization without industrialization (Fay and Opal 1999; Gollin, Jedwab, and Vollrath 2013; Jedwab 2013) and increased population 
concentrations in primate cities (Duranton 2008) are often viewed as serious urban and development problems.

This paper takes a different perspective and seeks to examine the extent to which growth and economic development are affected by urbanization. In this case, urbanization is no longer a change that follows from growth and needs to be accommodated. On the contrary, it is viewed as an integral part of the growth process. To evaluate how cities affect growth, it may seem natural to take a macroeconomic perspective and assess the effects of urbanization and its characteristics. Doing so involves taking a cross-country perspective and regressing growth on urbanization. Extremely, few studies take this approach, and cross-country growth regressions have come under heavy criticism. ${ }^{2}$

Instead, it is useful to reframe the question about the effects of urbanization on growth as a question about the effects of cities on worker productivity over different time horizons. Are workers more productive when they move to cities? Do they become more productive in cities? If yes, over what time horizon, how, and to what extent? The general answer is that workers in cities benefit from agglomeration economies, which take place through a variety of channels: resource sharing, quicker and better matching, and more learning. Section 2 provides a discussion of these issues. The bottom line is straightforward: cities have a positive effect on productivity and wages. There is a short-run effect in which workers are more productive on average in large cities than in small cities and in small cities than in rural areas. There is also a medium-run effect in which workers learn more in cities and gradually become more productive.

This greater productivity of labor in cities does not exist in a void. Urban workers hold jobs that allow them to be more productive. Section 3 broadens the discussion to job creation and firm dynamics in cities. More productive jobs in cities need to be created. Innovation, entrepreneurial activity, and firm growth all play crucial roles in this respect. Additionally, more productive jobs do not remain more productive forever. This productivity advantage is constantly eroded and needs to be constantly recreated. The process of creative destruction in cities (i.e., more firm entry and exit and a higher portion of innovative young firms) is also fundamental.

The dynamics of firms and jobs in cities are shaped by the broader characteristics of urban systems in the long run. In section 4, we highlight major differences between cities in developing countries and more advanced economies. In short, the urban system of many developing countries often acts as a brake on economic growth. A major challenge for these countries is to ensure that their urban systems act as drivers of economic growth. More specifically, cities in developing countries appear to be far less functionally specialized compared with cities in more advanced economies. This phenomenon hampers the dynamism of the largest cities, which are burdened by many ancillary activities in developing countries. These activities 
add to urban crowding without adding to agglomeration benefits. Better infrastructure, particularly better transportation infrastructure, and a reduction in favoritism toward large cities may be a way to remedy these problems. Policies to foster job creation directly may be tempting, but their record in more advanced economies is unsatisfactory.

In addition, developing cities function less efficiently and face challenges that differ from those of cities in more advanced economies. Appropriate management of the transition to full urbanization, a strengthening of urban governance, a reduction in labor market duality with the gradual integration of informal workers into the formal labor market, and a reduction or full elimination of land market duality are key challenges that must be addressed for developing cities to take full advantage of agglomeration effects and foster aggregate growth.

Because the literature on the issues discussed here is often extremely thin for developing cities, the exposition proceeds as follows. It first discusses the most recent findings about cities and various aspects of economic growth. Although much of the evidence comes from developed economies, this examination allows us to develop a rich vision of how cities can affect growth. Then, the evidence that relates specifically to developing cities is discussed. It is sometimes difficult to do more than highlight existing gaps in our knowledge and conjecture about how far the evidence can be extrapolated to developing cities.

\section{Cities, Productivity, and Wages}

The most immediate way for cities to foster economic growth and development is by making urban labor more productive. More specifically, we are interested in knowing whether households are more productive in cities than in rural areas and more productive in larger cities than in smaller cities. Ideally, we would like to be able to compare the same households across locations and assess their income, consumption, human capital acquisition, and quality of life. Because of a lack of data on many aspects of urban life, much of the literature focuses on wages and productivity and attempts to measure an urban wage or productivity premium.

\section{The Link between City Scale and Labor Productivity}

Cities enjoy a productive advantage over rural areas, and this advantage is larger for larger cities. This conjecture dates back at least to Adam Smith (1776) and was more fully articulated by Alfred Marshall (1890). The positive association between various measures of productivity and urban scale has been repeatedly documented since Shefer (1973) and Sveikauskas (1975). The fact that larger cities obtain higher scores on many productivity metrics, from wages to output per worker or 
the total factor productivity of firms, is now beyond doubt. Most of the studies reviewed by Rosenthal and Strange (2004), Melo, Graham, and Noland (2009), and Puga (2010) measure an elasticity of wages or firm productivity with respect to city employment or urban density of between 0.02 and 0.10 . That is, a city that is $10 \%$ larger in population offers wages that are 0.2 to $1 \%$ higher.

This type of work involves regressing an outcome variable by location on a measure of agglomeration. In the early literature, the typical regression of choice involved using output per worker as the dependent variable and city population as the explanatory variable. In the early 1990s, authors often employed more indirect strategies and began to use variables such as employment growth or firm creation as outcome measures (e.g., Glaeser, Kallal, Scheinkman, and Shleifer 1992; Henderson, Kuncoro, and Turner 1995). More recently, the literature has moved to microdata and returned to more direct outcome measures, namely the total factor productivity of firms and wages. Importantly, the focus is on differences in nominal wages between cities that reflect differences in productivity rather than on differences in real wages, which would measure differences in the 'standard of living'. We return to this distinction below, but for now, we examine productivity studies that typically estimate a regression such as

$$
\log w_{i c(i)}=\alpha \log \operatorname{Pop}_{c(i)}+\eta_{c(i)}+u_{i}+\varepsilon_{i c(i)}
$$

where $c$ denotes cities and $i$ denotes individuals or groups of individuals. The dependent variable is $\log w$, the log of the wage, and the explanatory variables are log Pop, the $\log$ of population as a measure of urban scale; $\eta$, a city effect (usually proxied through a number of control variables at the city level); and $u$, an individual effect (often proxied through observable individual characteristics). Finally, $\varepsilon$ is an error term. The estimated value of the coefficient of interest, $\alpha$, is usually positive and significant.

A few comments regarding the choice of variables are in order. The dependent variable is the log of the wage. Regressions similar to (1) can be proposed using measures of firm-level productivity as the dependent variable. Although the two types of measures are not exactly equivalent, they are close substitutes. ${ }^{3}$ Using a population- or employment-based measure of agglomeration as the dependent variable of interest makes little difference to the results, given the high correlation between the two. After Ciccone and Hall (1996), density has often been favored relative to population because it appears to yield more reliable results. The reason is most likely that density-based measures of agglomeration are more robust to zoning idiosyncrasies. For instance, treating Washington and Baltimore as one large consolidated metropolitan area or two separate cities makes a substantial difference to their employment count but little difference to density. ${ }^{4}$ 
Recall that the question raised above involves comparing the same households or workers in different locations. The regression described by equation (1) compares the outcomes across different workers who chose to be where they are, which is potentially a very different matter. Put differently, there is a robust statistical association between productivity outcomes and agglomeration, but it is unclear whether the estimated coefficient $\alpha$ in regression (1) reflects a causal effect of agglomeration on wages. A closer examination of equation (1) reveals three possible sources of bias (Combes, Duranton, Gobillon, and Roux 2010). They all stem from the fact that the measure of urban scale, such as $\log P o p_{c(i)}$, is indexed by $c(i)$; that is, city $c$ is chosen by worker $i{ }^{5}$

The first source of bias is the possible link between city effects (which are not observed directly) and the variable of interest, i.e., city population or density. Put differently, the 'quantity of labor' may be endogenous, and it is reasonable to expect workers to go to more productive cities. A possible solution to this problem is to use instruments for city population or density (Ciccone and Hall 1996; Combes et al. 2010). These instruments need to predict current population patterns but must be otherwise uncorrelated with city productivity. Deep historical lags, such as the population from 200 years ago or soil characteristics, can do the job (at least under some circumstances - see Combes et al. 2010, for a discussion). Studies using these types of approaches typically find that correcting for the endogeneity of the population has only a mild downward effect on the estimation of the coefficient of interest $\alpha$.

The second main identification problem in the estimation of equation (1) involves a possible correlation between the measure of city population and individual effects. That is, the quality of labor may be endogenous, and we expect more productive workers to reside in larger cities (Glaeser 1999; Behrens, Duranton, and RobertNicoud 2014). A first possible solution to this problem is to control for an extensive set of individual characteristics (Bacolod, Blum, and Strange 2009; Glaeser and Resseger 2010). A more drastic solution is to use (whenever possible) the longitudinal dimension of the data and impose worker fixed effects, as done by Combes, Duranton, and Gobillon (2008). The endogenous quality of labor seems to be an important source of bias in the estimation of equation (1). The estimated value of $\alpha$ is typically reduced by 30 to 50 percent when extensive individual controls or worker effects are used. ${ }^{6}$

The third source of bias in the estimation of equation (1) is the possibility of a correlation between the error term and the measure of city population of interest. If, for instance, workers move more easily from large cities to small cities than the opposite in case of a good external wage offer, this will create another source of bias, which, in this particular situation, leads to an underestimate of agglomeration economies. No satisfactory solution to this problem has been proposed so far. ${ }^{7}$ 
At this point, the conclusion of the agglomeration literature is that there is a causal static effect of cities and urbanization on wages in more advanced economies, but this effect represents only approximately half the measured association between city population or density and wages (or alternative measures of productivity). The rest of the association between population or density and wages reflects the sorting of more productive workers in larger and denser cities and, to a lesser extent, reverse causality and workers moving to more productive places. Recent investigations that address the concerns mentioned above find agglomeration elasticities of approximately 2 to 4 percent. Thus, these studies suggest rather modest static effects of cities on productivity.

Beyond developed economies, the association between urban scale and productivity has been documented in a number of developing countries, including China, Colombia, Korea, Indonesia, India, and Brazil. A detailed discussion of these studies can be found in Duranton (2008), Overman and Venables (2005), and Henderson (2005). These three reviews lament the paucity of work estimating agglomeration effects in developing countries and call for more work on the topic. Six years after the last of these surveys was written, this call has yet to be answered. There are only a handful of recent studies not reviewed in these surveys. These studies focus on Turkey (Coulibaly, Deichmann, and Lall 2007), China (Bosker, Brackman, Gerresten, and Schramm 2012; Combes, Démurger, and Shi 2013), India (Chauvin, Glaeser, and Tobio 2013; Ghani, Kanbur, and O'Connell 2013a), and Colombia (Duranton 2014a).

Methodologically, the literature on agglomeration effects in developing countries is often less advanced, and identification concerns have not been taken seriously. In the rare cases where they have been considered (such as Combes et al. 2013 for China; Chauvin et al. 2013 for India; Duranton 2014a for Colombia), three interesting features occur. First, as in developed economies, better controls for individual effects lower the estimates of the agglomeration elasticities. This finding is unsurprising because larger cities in developing countries tend to be populated by more educated workers. Second, in China and India, instrumenting for city size tends to raise the estimates for agglomeration effects instead of lowering them if we expect workers to move to high-wage cities. This may occur because policy in these two countries has sought to limit the migration of workers to larger and more productive cities. Hence, this perverse finding may not be as perverse as it seems and may only reflect a different policy context for these two countries. Third, after the best attempts to address estimation issues, estimated agglomeration effects in China and India remain much higher than the corresponding coefficients for developed economies. For instance, Combes et al. (2013) suggest agglomeration externalities of 10 to 12 percent for China. In Colombia, the estimated agglomeration effects are also higher than in developed economies, but the difference is smaller. A deeper understanding of what drives this heterogeneity in agglomeration effects is an obvious research priority. 


\section{What are the Sources of Agglomeration Benefits?}

After questioning its causal aspect, the second key question about the estimation of agglomeration effects involves their sources. When asking about the 'sources' of agglomeration, the literature frequently confuses two separate questions. The first involves which markets are affected by these agglomeration effects, and the second involves which mechanisms actually occur. Regarding the 'where' question, it is customary, after Marshall (1890), to distinguish the markets for (intermediate) goods, the market for labor, and the (absent) market for ideas and knowledge. In terms of mechanisms, Duranton and Puga (2004) distinguish among sharing, matching, and learning mechanisms. 'Sharing' involves the many possible benefits from the mutualization of specialized input providers, the diversity of local goods, the division of labor, or risks. 'Matching' involves the greater probability of finding another party, such as a worker, an employer, a supplier, or an investor, and the greater quality of the match with that party. Finally, 'learning' involves better generation, diffusion, and accumulation of knowledge. The latter set of mechanisms is regularly referred to as knowledge spill-overs.

Because of the wide variety of possible mechanisms and the markets in which they can occur, the literature that investigates the sources of agglomeration benefits is much more heterogeneous than the literature that attempts to measure the overall benefits of agglomeration, which naturally coalesces around the estimation of equation (1) or some variant of it.

First, there is a diversity of work that provides evidence of an association between some aspect of agglomeration, such as a particular mechanism or market, and measures of agglomeration such as city size. Let us take only a few recent examples (see Puga (2010) for a more exhaustive discussion). Holmes (1999) provides evidence of a strong association between urban scale and greater outsourcing to other firms, consistent with the importance of input-output linkages. Overman and Puga (2010) show that sectors in which establishments face more idiosyncratic risks tend to cluster more, consistent with the standard argument of better risk sharing in labor market pooling. Charlot and Duranton (2004) show that workplace communication, particularly communication with other workers outside the firm, is greater in larger cities and brings higher wages, consistent with standard spillover arguments. Also consistent with spillover arguments, Jaffe, Trajtenberg, and Henderson (1993) show that innovators are more likely to cite patents invented nearby than remote patents.

Taken together, these studies suggest that many of the agglomeration mechanisms de- scribed by the theoretical literature are at work in a variety of markets. This conclusion must be taken cautiously, however. Establishing the direction of causality in this type of work is even more difficult than when attempting to measure the overall effects of agglomeration.

To show that a given factor, such as communication spillovers, is a key channel through which agglomeration benefits percolate, one must establish two different 
causal effects. First, one must show that urban scale has a positive causal effect on this factor. This is basically the same regression described by equation (1), except the dependent variable is now the factor under consideration instead of wages. The identification issues are equally challenging. Then, one must show that the factor under consideration (spillovers, in our example) affects the final outcome of interest, such as wages. This is extremely difficult because other agglomeration channels may also be at play and may affect wages.

Given the difficulty of measuring many aspects of agglomeration and given that the list of possible agglomeration sources is fairly open, considering all sources of agglomeration in one regression is not a feasible option. A more reasonable path forward, following Ellison, Glaeser, and Kerr (2010), is to consider several classes of agglomeration sources in the same approach. Ellison et al. (2010) assess how much labor pooling, input-output linkages, and spillovers account for coagglomeration between industries in the United States. They use a measure of industry co-agglomeration and find more co-agglomeration among (i) industries that buy from each other, (ii) industries that use a similar workforce, and (iii) industries that share a common scientific base. To reduce the possibility that co-agglomerated industries end up buying from each other or using similar workers because of their physical proximity, they instrument their US measures of input-output linkages and labor pooling using corresponding UK data. Of course, if the biases are the same in the United Kingdom as in the United States, these instruments are of limited value. ${ }^{8}$ Another caveat is that input-output linkages may be more easily measured using input-output matrices than spillovers using patent citations. This can also lead to biased estimates because a positive correlation with both linkages and spillovers is likely to be picked up primarily by the better-measured variable (i.e., linkages). Ellison et al. (2010) confirm that the three motives for agglomeration they consider are at play, with input-output linkages playing a more important role according to their results.

There has been almost no work on the sources of agglomeration effects in developing countries. The main exception is Amiti and Cameron (2007), who use an empirical strategy that resembles that of Ellison et al. (2010) to examine the determinants of the productivity of firms in Indonesia. Their estimations strongly underscore the importance of input-output linkages. This result and the sometimes larger agglomeration effects for developing countries discussed above lead to an interesting conjecture. In many developing countries, trade costs with other cities or with foreign countries are particularly high. This would imply that the proximity to suppliers of intermediate goods becomes more important and explains stronger agglomeration benefits. This is only a conjecture, of course, and we discuss transportation issues below.

Even if we abstract from the uncertainty around these results, the notion that several mechanisms, each operating in several markets, contribute to agglomeration benefits is problematic for policy. At their heart, agglomeration benefits rely on 
market failures associated with the existence of small indivisibilities with sharing mechanisms, thick market effects with matching mechanisms, and uncompensated knowledge transfers with learning mechanisms. There may be many market failures at play in many markets. In turn, this implies that there may be no hope of fostering agglomeration economies through a small set of simple policy prescriptions.

\section{Heterogeneity in Agglomeration Benefits}

Before going further, it is important to note that agglomeration benefits are not 'monoliths' that apply equally to all workers in all cities depending only on their overall size. The literature provides evidence about three sources of heterogeneity.

The first involves the sectoral scope of agglomeration benefits. Agglomeration effects within sectors are referred to as localization economies, and agglomeration effects across sectors are referred to as urbanization economies. When estimating a more general version of regression (1) that accounts for both city size or city density and the degree of same-sector specialization, the extant research has found evidence of both localization and urbanization effects. There is also evidence of significant heterogeneity across industries. This heterogeneity follows an interesting pattern. Following Henderson et al. (1995) for the US, it appears that more technologically advanced industries benefit more from urbanization economies, whereas more mature industries benefit more from localization economies. Interestingly, Henderson, Lee, and Lee (2001) obtained very similar results for Korea.

However, the estimations of Combes et al. (2008) also indicate that in France, the benefits from localization economies are smaller than those of urbanization economies and are mostly uncorrelated with local wages. Put differently, increased local specialization has only small benefits and does not contribute to making workers richer.

The second key form of heterogeneity in agglomeration effects is that not all workers benefit equally from urban scale. Equation (1) estimates an 'average' agglomeration effect. As highlighted by Wheeler (2001) and Glaeser and Resseger (2010), agglomeration effects appear stronger for more educated workers in the United States. Consistent with this finding, Bacolod et al. (2009) find that individuals with better cognitive and people skills benefit more from being in larger cities. In turn, a higher wage premium for more educated workers in larger cities should provide stronger incentives to more skilled workers to locate there. Hence, these results are consistent with the well-documented fact that workers in larger cities in more advanced economies tend to be more educated and better skilled (Berry and Glaeser 2005; Combes et al. 2008; Bacolod et al. 2009). ${ }^{9}$

Very little is known about differences in agglomeration benefits across skill groups in developing cities. For Colombia, Duranton (2014a) provides evidence of, if anything, lower returns for university-educated workers in large cities. This 
phenomenon occurs despite a strong sorting of these workers in large cities. This may be the outcome of better amenities in large cities leading more skilled workers to sort into these cities and thereby depress the returns to education there. More evidence is obviously needed.

Finally, although not all workers benefit equally from agglomeration effects, it also appears that not all workers contribute equally to these effects. There is a large body of literature on human capital externalities suggesting that workers enjoy higher wages when surrounded by more educated workers. Estimates of urban external returns to education in cities are typically between 50 and 100 percent of the corresponding estimates of private returns to education, particularly for university graduates. These findings are robust to a number of estimation concerns and suggestive of large effects. ${ }^{10}$ It is beyond the scope of this paper to review this literature extensively. See Moretti (2004) and Duranton (2006) for more in-depth surveys and discussions. Early findings in the literature were generated from US data, but they have been confirmed for most large developed economies. These findings have also been replicated for Malaysia (Conley, Flyer, and Tsiang 2003), China (Liu 2007), Russia (Muravyev 2008), Chile (Saito and Gopinath 2011), and, in further unpublished work, for a number of other countries, including Colombia, India, and Turkey.

\section{Worker Learning and Dynamic Agglomeration Effects}

There is emerging evidence from US and European data that wage growth also depends on city size/density. To demonstrate this, one can estimate a regression along the lines of regression (1) using wages in the first difference instead of in levels as the dependent variable:

$$
\Delta_{t+1, t} \log w_{i c(i)}=\alpha \log \operatorname{Pop}_{c(i) t}+\eta_{c(i)}+u_{i}+\varepsilon_{i c(i) t},
$$

where $\Delta$ is used to note time differences between $t$ and $t+1$. Among a number of papers, Peri (2002) and Wheeler (2006) confirm that wage growth is stronger in larger cities. Although this result appears robust in many advanced countries, evidence from developing countries is still lacking.

Because the structure of regression (2) is the same as that of regression (1) for the static estimation of agglomeration economies, it suffers from the same identification problems. First, rather than being causal, the association between agglomeration and wage growth may be explained by the sorting of workers with faster wage growth in larger cities. For instance, 'fast learners' may tend to locate in larger cities. Using the same sort of fixed-effect strategy described above and applying it to a regression such as (2), Freedman (2008) nonetheless shows that this type of result holds even after controlling for the fact that some workers may experience higher wage growth independently of their location. ${ }^{11}$ 
Although the result that wages grow faster in cities is frequently interpreted as evidence of faster learning in cities and knowledge spillovers, the mechanisms that drive it are unclear. In the same way that regressing wages in levels on a measure of urban scale in equation (1) does not tell us anything about the sources of static agglomeration economies, regressing wage growth on urban scale in equation (2) is equally uninformative about the mechanisms driving agglomeration dynamics. Interestingly, Wheeler (2008) shows that young workers tend to change jobs more often in larger cities, whereas the opposite holds for older workers. This type of evolution is consistent with a matching model in which workers can find their "ideal match' more quickly in larger cities and then stick to it. Such a mechanism could explain both faster wage growth and eventually higher wages in larger cities.

As proposed by Glaeser and Maré (2001), evidence about learning in cities can come from the fact that workers retain some benefits from agglomeration after they leave their city. Consistent with this finding, Combes, Duranton, Gobillon, and Roux (2012c) find that 'worker skills', as measured by their fixed effect in a wage regression, do not differ much between less dense and denser areas in France for young workers. However, when older workers come from denser areas, they can command much higher wages than similar workers from less dense areas. This effect seems to be driven by labor market experience in denser areas rather than by increased sorting of intrinsically more skilled workers.

De la Roca and Puga (2012) provide the most comprehensive treatment of these urban learning issues to date using Spanish data. They assess agglomeration benefits in terms of both wage levels and wage growth. Their findings suggest the existence of both a level effect of cities on wages (of the same magnitude as those discussed above) and a dynamic effect. Over the long run, workers in large cities seem to gain about as much from each of these two effects. Confirming these findings for developing cities is, of course, a priority.

To sum up, this discussion of agglomeration economies, which focuses mainly on workers and jobs, reaches a number of interesting conclusions. First, larger cities make workers more productive. There is both a static and a dynamic component to these gains. A static elasticity of wages with respect to city population of 0.03 - as typically found in developed economies_implies that a worker receives a 23 percent higher wage when moving from a tiny city with a population of 5,000 to a large metropolis with a population of 5 million. Taking an elasticity of 10 percent, as found by Combes et al. (2013) for China, leads to a much more significant gain of 100 percent. Over time, dynamic effects make this urban premium larger. Assuming an extra 3 percent from learning in the medium run of 3 to 10 years, as De la Roca and Puga (2012) find for Spain, yields another 23 percent from the same move. Although longrun gains of 50 to 125 percent are not miraculous, they are nonetheless sizeable.

These numbers are, of course, only an illustration of the magnitudes at stake. They do not constitute a welfare pronouncement. Cities offer pecuniary benefits, 
such as higher wages in both the short and medium runs, as discussed above. They also offer non-pecuniary benefits such as a greater diversity of goods and services (Handbury and Weinstein 2010; Couture 2013). However, cities also generate pecuniary costs such as higher prices for housing and longer commutes and nonpecuniary costs such as, often, worse pollution and more crime.

Although the balance between costs and benefits is not precisely known, three elements are worth keeping in mind. ${ }^{12}$ First, mobile labor is expected to go where welfare is highest. Even in countries where mobility is restricted, households vote with their feet and move to cities in large numbers. ${ }^{13}$ This phenomenon is certainly consistent with higher welfare in cities. Second, some urban costs, such as higher land costs, are only transfers. Although they do not benefit newcomers who do not own land, higher land costs in larger cities are benefits that accrue to land owners. ${ }^{14}$ Third, urban costs are typically only paid when households reside in cities, whereas urban benefits that arise from learning are retained by households even after they leave a city. Hence, the choice to reside in cities should be viewed as an investment made by households.

Where does this leave us in terms of policy implications? The key conclusion is that the economic gains from urbanization are significant, and urbanization should be embraced rather than resisted. Cities offer both short-term benefits by raising worker productivity and longer-term benefits in the form of more worker learning. One may be tempted to go further and attempt to 'foster agglomeration effects'. This temptation should nonetheless be resisted. We are too far from knowing enough about the sources of agglomeration to implement any meaningful policy in that direction.

\section{Job and Firm Dynamics within Cities}

So far, we have observed that a strong case can be made that developing cities provide both a significant one-off productivity increase to workers and a more sustained improvement in their skills, which can be then be taken elsewhere. Although an important development step, urbanization may not guarantee self-sustained growth over long periods of time. It is also unclear how the productive advantage of cities described above can be sustained. To understand what underlies this productive advantage, it is important to make the simple observation that urban workers hold jobs that allow them to be more productive. Although jobs are usually viewed as a veil when we model production in theoretical models, they matter in practice. Higher labor productivity in larger cities is not about doing the same thing as in smaller cities more efficiently. Instead, the productive advantage of cities is about doing different things and doing them differently. That is, to receive higher wages, workers need 'better jobs'. Firm dynamics are often the vector of these changes. 
Examining several aspects of firm dynamics in cities-innovation, firm creation and growth, and factor allocation and reallocation across firms-will allow us to gain a better understanding of how the productive advantage of cities can be sustained (or not) over time. Doing so will also provide an important step toward understanding why and how cities can foster self-sustained growth.

\section{Innovation}

Starting with innovation, the first salient feature of the geography of innovative activity is that research and innovation is much more concentrated than production in most industries (Audretsch and Feldman 1996). Interestingly, this tendency seems particularly strong for industries that are more intensive in skilled labor and for research and development. It is also the case that a strong concentration of research and development often occurs in large metropolitan areas.

These location patterns for innovative activity are consistent with the notion that cities have a positive effect on innovation, just like they have on wages. More direct evidence can be found in Feldman and Audretsch (1999) and Carlino, Chatterjee, and Hunt (2007). To measure innovation, Feldman and Audretsch (1999) count all new product innovations in US metropolitan areas for a broad set of technologies and sectors in 1982. They find no evidence of urban scale effects but find that samesector specialization is strongly negatively associated with innovation, whereas a diversity of employment in technologically related industries is strongly positively associated with innovation, as originally suggested by Jacobs (1969). They also find strong positive innovation effects associated with the presence of smaller establishments.

Using the number of patents par capita as the dependent variable, Carlino et al. (2007) find evidence of strong agglomeration effects for innovative activity. Their estimate of the elasticity of patenting per capita with respect to employment density is approximately 0.2 . This is several times the estimates reported above for the corresponding elasticity of wages. ${ }^{15}$ Although patenting may be argued to be a poor proxy for innovation, Carlino and Hunt (2009) confirm these results when patents are weighted by their number of citations. Thus, larger cities innovate more on a per capita basis, and these innovations are no less influential than are those developed in smaller cities.

Although this evidence is highly suggestive that cities affect innovation, there is, to the best of my knowledge, no work that focuses on the effects of innovative activity on cities, such as the effects of local innovation on urban population growth. Regressing urban population growth on innovative activity would raise some obvious identification concerns. In addition, a simple theoretical argument suggests that the effect of innovation on urban growth need not be positive. Obviously, product innovation in the form of either an entirely new product or the capture of an established product from another location is expected to add to a city's 
employment (Duranton 2007). ${ }^{16}$ Process innovation within a city can cut both ways. Employment increases with process innovation only if greater productive efficiency and lower prices lead to a more than proportional increase in demand. In the opposite case, process innovation implies a contraction of local employment. Remarkably, Carlino et al. (2007) show that Rochester, Buffalo, Cleveland, St. Louis, and Detroit, which are all in demographic decline, are also highly innovative cities. This finding suggests that, to some extent, the demise of these cities may be attributed to the fact that labor productivity increased much faster than demand in their industries.

Finally, innovative activity appears to change the nature of jobs in the cities where it takes place. As shown by Lin (2011), cities that patent more tend to have a greater proportion of what he labels 'new work', that is, jobs that did not exist a few years before. New work is also fostered by a greater proportion of educated workers and a diversity of industries, two other attributes of large cities.

To draw lessons for developing cities from these results about cities in developed economies, some caution is needed. Acemoglu, Aghion, and Zilibotti (2006) make a useful distinction between developed economies located at the technological frontier and developing countries within this frontier. The growth problem for developed economies is to push the frontier. For these economies, formal innovations and research and development play a crucial role. For developing countries, the problem is one of catch-up, where scientific advances and patenting play much less of a role. However, this does not mean that innovative activity, broadly construed, is irrelevant for those countries. To some extent, economic growth in developing countries is about firms' ability to produce new and better products and to produce them more efficiently. That is, firms in developing countries require product and process innovation, albeit in a way that is different from firms at the frontier. Being able to understand, adapt, and use knowledge developed in other countries is fundamental. In Colombia, for instance, the number of new patents is minimal, but a significant proportion of firms claims to be engaged in product and process innovation (Nieto Galindo 2007). Interestingly, innovation is also geographically concentrated. The departments of the 3 main cities in Colombia generate more than 70 percent of the innovations of the country, whereas they host less than 40 percent of the population. Hence, though the issue for developing countries is more about absorbing existing knowledge than generating completely new knowledge, large cities in developing countries should still have an important role to play in innovative activities by absorbing foreign knowledge and making sure it diffuses to the rest of the country.

To conclude on the links between innovation and cities, the extant literature supports the notion that cities affect the propensity to innovate either because of their sheer population size or because of the (diverse) structure of their production activities. The evidence about the effect of these innovations on the cities where they were developed is more complex. In particular, for a given city, being more innovative does not appear to mean higher growth in income per capita or even growth in population. 


\section{Entrepreneurship}

Entrepreneurship is another possible reason why cities offer better jobs and host more productive firms. First, cities affect entrepreneurship in the same way they affect wages and innovation. In a comprehensive analysis of the determinants of employment in new manufacturing start-ups across US cities, Glaeser and Kerr (2009) generate a rich harvest of facts. ${ }^{17}$ The first is the existence of scale economies. As a city grows larger, employment in new start-ups in this city increases more than proportionately. Depending on their specification, Glaeser and Kerr (2009) find an elasticity of employment in new start-ups per capita with respect to city scale between 0.07 and 0.22 . City population, city-industry employment, and sector effects explain approximately 80 percent of the variation in start-up employment across cities and sectors.

Consistent with a conjecture made initially by Chinitz (1961), Glaeser and Kerr (2009) also find that the presence of many small suppliers is strongly associated with employment growth in start-ups. In addition, they find evidence of mild Marshallian effects associated with labor market pooling and spillovers. Finally, city demographics, including their measure of 'entrepreneurial culture', have only limited explanatory power ${ }^{18}$ The 'Chinitz' finding about the importance of many small establishments is confirmed by Rosenthal and Strange (2010), who suggest that small establishments matter because they provide a greater diversity of specialized suppliers to local firms.

The analysis of Glaeser and Kerr (2009) has been recently replicated by Ghani, Kerr, and O'Connell (2011) for start-ups in formal manufacturing, informal manufacturing, and services in Indian districts. They find evidence of urban scale effects whereby the number of start-up increases more than proportionately with city population in services, though not in manufacturing. Similar to Glaeser and Kerr (2009) for the United States, the Indian evidence underscores the importance of small firms and broader measures of input-output linkages. Unlike in the United States, Ghani et al. (2011) also find that in India, district demographics (education in particular) matter. They also consider a number of variables not present in Glaeser and Kerr (2009). Importantly, their measure of district accessibility plays an important role similar to the stringency of labor laws, which, in India, varies across districts.

The other key feature related to the supply of entrepreneurs is that there is a strong local bias in entrepreneurship. Entrepreneurs tend to create their start-up in the place where they were born and/or where they have lived and worked before becoming entrepreneurs. This important fact was first documented by Figueiredo, Guimarães, and Woodward (2002) for Portugal and Michelacci and Silva (2007) for Italy and the United States. This finding has been further confirmed by several other studies in developed economies. Figueiredo et al. (2002) also show that when 
entrepreneurs choose a new location, this choice is strongly governed by agglomeration economies and proximity to large cities.

After examining the urban determinants of entrepreneurship, we now turn to the effects of entrepreneurship on their cities. It has been shown repeatedly that entrepreneurship plays a key role in urban evolutions. The key fact here is that growth in a city and sector over a period of time is strongly correlated with the presence of small establishments in that city and sector at the beginning of the period. This fact was first documented by Glaeser et al. (1992) and has been confirmed for other countries and time periods by many other studies. In an interesting extension of this type of research, Faberman (2011) documents that the majority of the variation employment growth across US cities can be accounted for by the birth and expansion of young firms. Employment growth in US cities is also positively correlated with greater job churning.

As in many of the correlations discussed above, the strong link between small firms and employment growth raises a key identification concern about the direction of causality. However, this issue has been neglected by the literature until quite recently. This is perhaps because the standard regression in this literature uses growth over a period as dependent variable and establishment size at the beginning of the period as explanatory variable. However, using a pre-determined variable as the explanatory variable in a regression does not guarantee its exogeneity. Local entrepreneurs could enter in large numbers in a city and sector if they foresee strong future demand. It is only natural that expectations of future growth should trigger entry today. That is the nature of business.

As a first step toward the resolution of this identification problem, Glaeser, Kerr, and Ponzetto (2010) examine whether the presence of many small firms in a city and sector is driven by the demand for entrepreneurship or by its supply. To the extent that they can be captured by higher sales per worker, demand factors do not appear to matter. Their findings point instead to the importance of the supply of entrepreneurship. This indirect approach, however, does not entirely solve the causality issue. To address it head on, Glaeser, Kerr, and Kerr (2012) take an instrumental variable approach. Returning to Chinitz's (1961) initial comparison of Pittsburgh and New York, they use the idea that cities closer to mines have been influenced by large mining firms. In turn, large firms are expected to reduce entrepreneurship by providing attractive employment opportunities for highly skilled workers. Large firms may also breed a local culture of 'company men', which in turn reduces entrepreneurship. In the data, proximity to historical mines is associated with larger establishments today, even in completely unrelated sectors. Using this instrument, the authors estimate an even larger effect of entrepreneurship on city growth than the one measured directly from the data. Because a mining past can be associated with a general decline in manufacturing, Glaeser, Kerr, and Kerr (2012) replicate their main findings for cities outside the Rust Belt. These findings also hold when, 
instead of focusing on overall employment, they only examine service sectors that are remotely tied to mining. Although these results require further confirmation and replication for developing countries, they support the notion that entrepreneurship is an important engine of city growth.

To sum up, extant evidence suggests that urban entrepreneurship is an important foundation of the productive advantage of cities. More specifically, the constant entry of new entrepreneurs appears to be a key mechanism that allows cities to sustain their greater productivity.

\section{Factor Allocation and Reallocation}

Finally, we take a broader view and turn to factor allocation and reallocation. Better factor allocation or factor reallocation in cities may be at the root of the productive advantage of cities. The literature that examines factor allocation and reallocation makes two important claims. The first is that a large fraction of productivity growth at the country level can be accounted for by the reallocation of factors from less productive to more productive firms. Foster, Haltiwanger, and Krizan (2001) for US manufacturing and Foster, Haltiwanger, and Krizan (2006) for US services show that exiting firms are less productive than continuing ones and that, conditional on survival, start-ups have higher productivity than more mature firms. Put differently, a large share of productivity growth can be accounted for by a churning process in which low productivity firms are replaced by new and more productive start-ups. As shown by Foster, Haltiwanger, and Syverson (2008), considering that startups have lower margins (and thus a lower apparent productivity when using standard approaches to the estimation of productivity) only strengthens these results. These important findings have been confirmed for many countries (Bartelsman, Haltiwanger, and Scarpetta 2004), including detailed studies using high-quality data from developing countries such as Colombia (Eslava, Haltiwanger, Kugler, and Kugler 2004).

The second important claim made by the reallocation literature is that 'misallocation' can account for a large share of existing productivity differences across countries. To understand this point better, consider the influential work of Hsieh and Klenow (2009). They first note that, in equilibrium, marginal products should be equalized across firms. If the demand for the varieties produced by firms has a constant elasticity of substitution, this implies an equalization of the product of their price multiplied by their 'true productivity' (which is the ability of firms to produce output from inputs). This (price times true productivity) product is what is estimated as 'total factor productivity' in most productivity exercises. We may call this quantity 'apparent productivity' instead. ${ }^{19}$ Obviously, firms' apparent productivities are never equalized in real data. Hsieh and Klenow (2009) interpret this as evidence of factor misallocation. Using the highly dispersed distribution of manufacturing productivity 
in China and India, they calculate extremely large potential costs from such misallocation. Acknowledging that a perfectly efficient allocation may be impossible, they compute that the productivity gains for manufacturing in China and India would still be approximately 50 percent if their level of misallocation could be reduced to that observed in the United States. Using a different approach that uses the covariance between size and productivity at the firm level to measure misallocation, Bartelsman, Haltiwanger, and Scarpetta (2013) find substantial differences between countries. ${ }^{20}$ These differences in misallocation are correlated with the large existing differences in aggregate performance between countries and are predicted to explain a sizeable fraction of them.

To the best of my knowledge, there is no study in the spirit of the cross-country work of Foster et al. (2001) that attempts to relate greater churning/reallocation at the firm level and higher productivity growth at the urban level. However, there is a strong suspicion that larger cities should exhibit more churning because, as already argued, larger cities are more innovative, experience more entry and exit, and have a greater fraction of their workforce in 'new work'. At the same time, there is no indication that this greater amount of churning in larger cities is associated with higher productivity growth in those cities, unlike what occurs at the country level.

We know little about productivity growth in cities. According to Lin (2011), the greater proportion of workers employed in new work in larger cities is not associated with faster productivity growth. In a rare study of the broader determinants of productivity growth in Italian cities, Cingano and Schivardi (2004) highlight the importance of both specialization and employment size. However, given that specialization and employment size are negatively correlated, their positive effects arguably cancel out. Hence, more churning does not appear to lead to faster productivity growth in cities.

To confirm this conclusion, note that workers are somewhat mobile across cities. Thus, more churning associated with faster productivity growth in larger cities should imply a divergence in the population growth rates. There is no evidence of such divergence. ${ }^{21}$ This lack of a result regarding the link between churning and productivity should not be taken as negative evidence against the reallocation literature. As argued in the next section, it is possible that reallocation does not take place only within cities but also across cities.

Turning to the second claim about misallocation, Combes, Duranton, Gobillon, Puga, and Roux (2012b) show that the distribution of firm productivity is unambiguously more dispersed in larger cities in France. In the framework of Hsieh and Klenow (2009), this can be interpreted as greater misallocation in larger cities. This seems difficult to believe. The evidence about static agglomeration effects discussed above is instead best interpreted as agglomeration economies leading to a better allocation of resources (in a broad sense) in larger cities. Performing the same productivity decomposition as Bartelsman, Haltiwanger, and Scarpetta (2013), 
Combes et al. (2012b) find a similar covariance between establishment size and productivity in large and small cities, suggesting a similar level of efficiency in the allocation of factors to firms.

To sum up, the evidence about firm dynamics and cities presented in this section suggests an interesting tension. Larger cities are more innovative, more entrepreneurial, experience more churning and reallocation, and generally enjoy a greater 'economic dynamism'. Although much of the formal evidence is from developed economies, observation and casual evidence suggests the same is true in developing countries. At the same time, large cities do not appear to enjoy most of the benefits associated with such dynamism because neither productivity nor population appears to increase faster in larger cities. To resolve this tension and understand why the greater economic dynamism of large cities does not translate into faster growth in income or in population, we need to consider large cities to be part of an urban system.

\section{Urban Systems}

To deepen our understanding of the effect of cities on growth, we now need to think about cities as small open economies that interact with other cities and rural areas. They are part of an 'urban system'.

\section{Forms of Urban Specialization}

Starting with innovation, recall that larger cities offer many advantages for both product and process innovation. More specifically, as highlighted by Jacobs (1969), cities favor the circulation and cross-fertilization of ideas. This naturally leads to more product innovations and is consistent with the evidence of Feldman and Audretsch (1999) discussed above. For process innovation, Duranton and Puga (2001) underscore the greater availability of intermediate goods in large cities, which allows firms to proceed through trial and error at a faster pace. In short, the greater ability of larger cities to innovate may simply be another manifestation of agglomeration economies. The key difference with many static aspects of agglomeration economies discussed above is that with dynamic effects, co-location is not needed all the time. More precisely, spillovers may matter to develop an innovation, but after an innovation is developed, co-location is no longer needed. Quite the opposite, larger cities are more expensive places to produce. After the dynamic benefits from agglomeration have been exploited, it can make sense for firms to relocate. Often, the entire firm does not need to relocate because only the production of particular products is involved.

Patterns of establishment relocation in France are highly consistent with this type of product cycle. As shown by Duranton and Puga (2001), approximately 
75 percent of French establishments that relocate do so from a city with abovemedian diversity to a city with below-median diversity and above-median specialization in the same sector. In addition, as documented by Fujita and Ishii (1998), large Japanese multinationals in the electronic sector produce their newest products in 'trial' plants near Tokyo and Osaka. Previous generations of products are produced in rural locations in Japan, other advanced Asian countries, and even less advanced Asian countries for products with a low degree of sophistication. Hence, as their products mature, firms still search for agglomeration economies but put greater weight on the benefits of specialization. Large cities act as nurseries for new goods and new products. Once mature, new goods and products are best produced in more specialized places.

There is no formal evidence about this issue, but observation suggests that in most developing countries, the nursery cities phenomena are not at play to the same extent as in developed economies. ${ }^{22}$ Although the largest cities in developing countries are the centers of innovation (understood in a broad sense to include the adoption of more advanced knowledge from other countries), there is little in terms of relocation of the production of mature products to secondary specialized cities. Instead, both more advanced and mature products are produced in the largest cities. This situation likely makes these cities larger than they should be and increases congestion. Mature products also end up being produced in the most expensive cities at a higher cost. Smaller cities may suffer even more from this because they are stuck with the production of the most backward products without receiving a constant inflow of new goods to produce from their metropolises.

In more advanced economies, cities also specialize by sector. There are countless examples of age-old specializations, including knives and blades in Sheffield or jewelry in Birmingham in the United Kingdom, as described by Alfred Marshall (1890). More systematic evidence about specialization in US cities is provided by Black and Henderson (2003). However, this tendency for cities to specialize, while still present in the data, has diminished over time, as documented by Duranton and Puga (2005). The same authors also document a rise in the functional specialization of US cities with the emergence of cities specialized into management type functions, whereas others specialize more into production activities. ${ }^{23}$ This rise in functional specialization is rationalized by Duranton and Puga (2005) in a model where lower communication costs make it easier for firms to separate management from production. Because these activities benefit from very different types of agglomeration economies, this separation is beneficial, provided that the cost of separating activities is low enough. In turn, this separation of activities reinforces the functional specialization of cities.

There is limited evidence about the sectoral specialization of cities in developing countries. Ghani, Kerr, and Tewari (2013b) examine patterns of specialization and diversity for manufacturing in Indian districts. ${ }^{24}$ They show evidence of declining 
specialization and rising diversification of Indian districts between 1989 and 2005. They also compare Indian districts with the US metropolitan areas that have the most manufacturing for which the levels of manufacturing employment are roughly the same. They find that Indian districts are somewhat more specialized and less diverse. Duranton (2014b), in contrast, finds increasing manufacturing specialization and decreasing manufacturing diversity in both Colombian municipalities and metropolitan areas over 1990 and 2005. Increasing manufacturing specialization, however, is counterbalanced by decreasing specialization and rising diversity in non-manufacturing sectors. Colombian municipalities and metropolitan areas are also less specialized and more diverse than US counties and metropolitan areas, respectively. It is also interesting to note that the share of manufacturing employment is unrelated to city population in Colombia, whereas it declines strongly with city population in the United States.

These multiple dimensions of specialization are part of well-functioning urban systems in more advanced countries. Additionally, the notion of cities being specialized by functions and activities is not static. Duranton (2007) argues that the process of continuous location and relocation of economic activity is a crucial aspect of the growth of those activities. To take a simple example, when George Eastman developed a new revolutionary technology in the photographic industry in Rochester, the industry relocated from New York to Rochester. Much later, as the technology developed by Eastman was superseded by the digital revolution, Rochester lost its status as the capital of the photographic industry. Beyond this illustrative example, more systematic evidence of such churning across cities is presented in Duranton (2007) for the US and France and in Findeisen and Südekum (2008) for Germany. Based on the case of Boston, Glaeser (2005) further argues that successful cities are those that are continuously able to reinvent themselves. The idea that different cities specialize into different functions and are able to change their specialization after negative shocks presupposes a fair amount of 'mobility' across cities. The first important dimension of mobility involves goods and services. It would make little sense for cities to narrowly specialize in an activity if its output could not be exported. Continuously changing patterns of specialization also require labor mobility.

Putting this all together, the evidence presented so far suggests a less advanced process of urban differentiation in developing countries than in more advanced economies. In turn, this lack of differentiation in urban functionality may limit the dynamism of cities in developing countries.

\section{Urban Labor Markets in Developing Cities}

In the rest of this section, we examine a number of urban factors that reduce both the efficiency of the urban system and the efficiency of cities directly. 
The first key difference between cities in developing and more advanced countries involves the functioning of their labor market. In most developing countries, there is a well-known duality in the labor market that usually involves a large informal sector alongside the formal sector. Aside from its detrimental implications for workers in the informal sector, this duality hinders urban development in several ways. First, it has been accused of inducing too much migration toward the largest cities, where most of the formal sector is located. ${ }^{25}$ Duality may also limit mobility across cities because jobs in the informal sector tend to be filled by word-of-mouth through social connections, which are lacking for newcomers. High barriers to 'good' jobs in the formal sector may also limit incentives for workers to improve their skills locally and thus limit the scope of agglomeration benefits.

To mitigate the effects of labor market duality, three broad types of policies are potentially available. The first is to improve the working of labor markets. Although this objective is certainly laudable, a discussion of this class of policies would go beyond the scope of this paper.

The second type of policy is to foster local job creation through 'place-based' policies. Such policies typically involve tax exemptions or subsidies associated with job creation within well- defined (and often tightly circumscribed) areas. These tools are frequently used to attempt to reduce the unemployment rate of the residents of poor areas in more advanced economies. Although the labor market failures in developed and developing countries differ and the scale at which such policies might be implemented in developing countries may be much broader than poor neighborhoods of 'rich' cities, there may be useful lessons to learn from the recent North American and European literature evaluating those policies.

Simply put, the general record of place-based policies is in doubt (Glaeser and Gottlieb 2008). Detailed evaluations of particular policies often reach negative conclusions. For the United States, Neumark and Kolko (2010) draw negative conclusions about the California enterprise zone program. Busso, Gregory, and Kline (2013) find evidence that the federal empowerment zone program boosted jobs locally, but they find no evidence of increased land values. Mayer, Mayneris, and Py (2011) also draw negative conclusions about the French urban employment zone program. Importantly, they find that the increase in employment within targeted areas is mainly accounted for by relocations from nearby areas. Similar displacement effects are found by Einiö and Overman (2011) for the United Kingdom. These authors also reach equally negative conclusions. ${ }^{26}$ Overall, the evidence suggests that these policies may create more problems than they solve and mostly inefficiently relocate economic activity.

The third class of policies attempts to foster job creations in a particular locality by helping firms in a given sector. These policies are usually referred to as 'cluster' policies and follow the work of Michael Porter (1990). They often entail the development of subsidized supportive institutions and infrastructure using public subsidies 
and various types of fiscal incentives. The review of the literature in Duranton (2011) draws negative conclusions about the benefits of cluster policies.

To conclude, there are serious problems with the functioning of local labor markets in developing cities. The evidence suggests that the main road ahead is to improve the functioning of labor markets everywhere and to avoid place-specific solutions. $^{27}$

\section{Urban Land Markets in Developing Cities}

The second key difference between cities in developing and more advanced countries involves the functioning of their land market. Similar to labor markets, land markets in developing cities are characterized by a duality between land used with appropriate property titles and leases and squatted land. Following a conjecture by De Soto (2000), recent empirical research has focused on the effects of the lack of effective, formal property titles that could prevent residents of squatter settlements from using their house as collateral. Informal land markets may thus be a major barrier to enterprise development. The empirical evidence about the relaxation of credit constraints associated with 'titling' policies is weak. Recent work points instead to increases in labor supply (Field 2007) and to the adoption of more middle-class values and attitudes (Di Tella, Galliani, and Schargrodsky 2007). Although this evidence about titling policies is relatively optimistic about the merits of such policies, the existing literature focuses nearly exclusively on residential land. The extent of land illegality for commercial land (from illegal street vendors to squatter manufacturing) is poorly measured, and the solutions are not well developed. ${ }^{28}$

\section{Roads and Infrastructure Linking Developing Cities}

The third key difference between cities in developing and more advanced countries involves infrastructure, particularly road infrastructure. Two strands of research need to be distinguished here. The first finds its roots in international trade and focuses on the estimation of the effect of 'market potential' variables. The market potential of a city is usually computed as the sum of the income (or population) of other cities weighted by their inverse distance to the city under consideration. Assuming transportation costs and other trade frictions associated with distance, many models of international and inter-regional trade generate the prediction that a location's income and wages will be determined by its market access (Krugman 1991; Krugman and Venables 1995; Head and Mayer 2004). The literature offers strong empirical support regarding the importance of market access for cities in developing countries. Using two different approaches, Lall, Koo, and Chakravorty (2003) and Lall, Shalizi, and Deichmann (2004b) underscore the importance of market access in India. Strong effects of market access are also found in Brazil (Lall, 
Funderburg, and Yepes 2004a; da Mata, Deichmann, Henderson, Lall, and Wang 2007) and Indonesia (Deichmann, Kaiser, Lall, and Shalizi 2005; Amiti and Cameron 2007). This within-country evidence is complemented by the literature that examines the importance of market access at the country level (Redding and Venables 2004; Head and Mayer 2011). ${ }^{29}$

The second strand of literature focuses more closely on the effects of infrastructure. Baum-Snow's (2007) pioneering work finds that the construction of the interstate highway system was a major impetus behind the suburbanization of US cities. Duranton and Turner (2012) also find that more kilometers of interstate highways in US metropolitan areas in the early 1980s led to faster population growth over the next 20 years. ${ }^{30}$

These results are confirmed by Holl and Viladecans-Marsal (2011) for Spain. For rural areas in the United States, Chandra and Thompson (2000) and Michaels (2008) find that new highways lead to a displacement of economic activity toward the counties served by these new highways and an increase in the demand for skills. For US metropolitan areas, Duranton, Morrow, and Turner (2014) find that highways lead to a greater specialization into 'heavy sectors', for which transportation costs are higher. That is, having more highways in a metropolitan area increases the weight of its exports but not its value. ${ }^{31}$

This type of approach is also being applied to developing countries. In a remarkable piece of work, Donaldson (2014) documents the effects of the construction of India's railroad network by its colonial power. He shows that railroads increased trade and reduced price differences across regions. Even more importantly, railroads increased real incomes and welfare. To minimize identification problems, he compares the network that was built with other networks that were considered but never developed. In related work on modern India, Ghani, Goswami, and Kerr (2012) show that a major upgrade of India's main highways had positive effects on the productivity and entry of plants in districts close to improved highways. In a slightly different vein, Jedwab and Moradi (2011) document that railway lines built by the British colonial power in Ghana for the exploitation of inland mines had a large effect on agricultural production of the main export crop, cocoa, which was more easily shipped to the coast. In turn, agricultural development bolstered urbanization. These effects are still present today as districts close to these rail lines are more developed.

In line with some of the arguments advanced above about the importance of transportation infrastructure for the decentralization of manufacturing activity away from large metropolises, Baum-Snow et al. (2013) underscore the importance of railroads in the decentralization of manufacturing production in China. ${ }^{32}$ Rothenberg (2011) shows similar effects regarding highways in Indonesia.

Storeygard (2011) provides evidence about the importance of inter-city transportation costs for inland African cities. Using new roads data for Africa and satellite 
data ('lights at night') to estimate economic activity, he assesses the effect of higher transportation costs. To circumvent the endogeneity of transportation costs (roads may be built to access growing cities), he uses arguably exogenous variations in oil prices. He finds an elasticity of economic activity with respect to transportation costs of approximately -0.2 .

All of these findings are suggestive of the profound and long-lasting effects of major transportation infrastructure. However, it is necessary to remember that major transportation networks are extremely costly investments.

\section{Urban Favoritism}

The last key difference between cities in developing and more advanced countries involves the effects of the favoritism by governments toward the largest cities. Although the reasons for primate city favoritism are debated (Ades and Glaeser 1995; Henderson 2005), there is little doubt that such favoritism occurs in many different ways. As argued in Duranton (2008), primate city favoritism harms the favored primate city by making it larger than it should be. It also harms smaller cities, which are, in effect, heavily taxed. The gap that is created between the primate city and other cities may also have negative dynamic effects because, for most educated workers, there is nowhere to go except to stay in this primate city. As a result, this may reduce the circulation of knowledge across cities. Reducing primate city favoritism and providing smaller cities with better local public goods (including education and health) is certainly a part of any solution.

\section{Conclusions}

For individual workers, cities in developing countries appear to bring significant benefits, in both the short run and the long run. However, when taking a broader look, the urban system of developing countries appears to involve far less functional differentiation across cities than in more advanced economies. This differentiation, with different cities playing different roles in the urban system, is important for the process of growth and development to proceed smoothly. Larger cities innovate and manage, whereas smaller cities often produce a narrow range of goods. Having larger cities do everything, as they often do in developing countries, reduces their dynamism and holds back small cities.

A variety of policies can be envisioned to solve this problem. The four most promising areas are general policies to improve the functioning of labor markets, ending primate city favoritism, favoring labor mobility (or, at least, not hindering it), and the development of major infrastructure to connect cities. 


\section{Notes}

Wharton School, University of Pennsylvania, 3620 Locust Walk, Philadelphia, PA 19104, US (e-mail: duranton@wharton.upenn.edu; website: https://real-estate.wharton.upenn.edu/profile/21470/). Also affiliated with the Centre for Economic Policy Research, the Spatial Economic Centre at the London School of Economics, and the Rimini Centre for Economic Analysis. I am grateful to Martin Rama and Yue Li for helping me frame the issues and to Henry Overman, three anonymous referees, and the editor for constructive criticisms on earlier drafts. Funding from the World Bank is gratefully acknowledged.

1. Closely related to this is the issue of how the overall concentration of economic activity may increase and then decrease during the process of development, as first conjectured by Williamson (1965). See Henderson (2005) or Kim (2008) for further discussions.

2. The main exception is Henderson (2003), who finds negative effects of urban primacy on economic growth. See also Brülhart and Sbergami (2009) for a perspective closer to Williamson (1965). For a critical review of cross-country growth regressions, see Durlauf, Johnson, and Temple (2005).

3. With competitive wage setting, we expect a higher coefficient on city population when wages are used as the dependent variable relative to regressions with total factor productivity. This is because higher productivity implies a more intensive use of capital, which further raises the marginal product of labor and thus wages. Confirming this, there is mild evidence of higher agglomeration coefficients when wage is used as dependent variable instead of firm productivity (Melo et al. 2009).

4. However, one must be careful not to use employment density with small sub-city units. In some countries, the densest parts of cities are also those that host the least-skilled jobs and pay the lowest wages. This would certainly include parts of Washington, DC and downtown Baltimore.

5. Again, it would be preferable to compare the same workers across the cities that they have chosen and those that they have not chosen. In the absence of randomized experiments, this is not possible. Greenstone, Hornbeck, and Moretti's (2010) quasi-experiment on 'million dollar plants' comes closest to this ideal for firms' location choices.

6. It is necessary to be careful; imposing worker effects improves the quality of the estimation but is not a perfect solution because it assumes that mobility is exogenous.

7. Considering mobility explicitly in this type of work is extremely challenging. First, individuals have a large number of discrete locations from which to choose. This raises serious computational problems. Second, an instrument is required that would explain location choices but not wages. It is unclear whether there is any variable that explains location but is otherwise uncorrelated with wages. The only serious attempt to address this problem thus far has taken place within the structural estimation of a pre-imposed model (Baum-Snow and Pavan 2012).

8. To make this discussion more concrete, consider, for instance, shipbuilding and fishing. These two industries co-agglomerate along the coasts in the US and the UK. The fishing industry also buys a large amount from shipbuilding. It would nonetheless be far-fetched to interpret this link solely as evidence for the importance of local input-output linkages because the co-location of these two industries is also largely explained by their need to be on a coast.

9. However, the general tendency for more skilled workers to be over-represented in larger cities is only somewhat modest in advanced economies. Behrens et al. (2014) estimate the elasticity of college graduates with respect to city population to be approximately 7 percent.

10. There are some unresolved tensions between the 'agglomeration' literature and the 'human capital externality' literature. The key variable of interest (city size or average education) of each body of literature is typically ignored (missing) in the other. In addition, the city size literature argues that agglomeration economies are higher for more educated workers, whereas the human capital externality literature finds that less educated workers benefit more from being surrounded by more highly educated workers. Given the positive correlation between city population size and average education, it would be desirable to reconcile these two findings within a consistent framework. 
11. Again, the fact that mobility is endogenous limits the validity of this strategy.

12. Looking at the pecuniary costs of French cities depending on their size, Combes, Duranton, and Gobillon (2012a) find a cost elasticity slightly larger than the agglomeration elasticity, suggesting that the net benefits of city size are close to being flat. Conducting a similar exercise for Colombian cities yields comparable results.

13. Of course, there could be some inefficiency inducing households to inefficiently move to cities, as suggested long ago by Harris and Todaro (1970). However, the literature has never found much support for this type of behavior (see Lall, Selod, and Shalizi (2006) and Duranton (2008) for reviews and discussions).

14. A reasonable case can be made that restrictive practices on the land market and the failure to redistribute these rents properly is inefficient and constitutes an obstacle to urban growth.

15. Interestingly, Carlino et al. (2007) also find that this elasticity of innovation with respect to employment density or population size is not constant across the urban hierarchy. Patenting per capita appears to peak at approximately 5,700 jobs per square kilometer or a city population size slightly below a million.

16. Strong evidence linking product innovation to subsequent employment growth is nonetheless still missing. Kerr (2010) documents that a 'breakthrough' innovation in a city leads to a wave of subsequent innovations. This increase in 'follow-up' innovative activity is particularly strong in research fields where foreign-born scientists are more numerous. This is arguably linked to the greater mobility of foreign-born vs. native scientists.

17. It is well known that the analysis of entrepreneurship is plagued by fundamental measurement problems. Self-employment captures most entrepreneurs, but unfortunately, it also captures many other workers who are not 'true' entrepreneurs. Using small firms is problematic for similar reasons. The entry of new establishments is also a highly imperfect measure, but for different reasons because it often measures establishments affiliated with an already established firm. To avoid these problems, one can focus on the more restrictive notion of new (independent) start-ups, which may be weighted by their employment.

18. Capturing the notion of 'entrepreneurial culture' is extremely difficult. For each sector, Glaeser and Kerr (2009) use the number of start-ups in other sectors. They find no association between startups in a sector and start-ups in other sectors of the same city after conditioning out other city variables.

19. To be more specific, true productivity is typically unobserved because one cannot easily condition out prices. Firm productivity studies do not measure the true ability of firms to generate output from inputs but rather their ability to generate value added.

20. Most models of market structure predict that more productive firms should be larger. The strength of the correlation between firm size and firm productivity should thus be indicative of how efficiently labor and capital are allocated. This exercise is known as the Olley-Pakes productivity decomposition (Olley and Pakes 1996).

21. If anything, the population growth rate of larger cities is lower. There is also evidence that more educated cities grow faster (see Duranton and Puga (2013) for a broader discussion of urban growth patterns).

22. Korea has been successful in this transition toward more differentiated cities (Henderson et al. 2001). Progress in other developing countries seems more uneven.

23. Further evidence is provided in Aarland, Davis, Henderson, and Ono (2007) and other related works by Vernon Henderson and Yukako Ono.

24. Although they are negatively correlated, diversity and specialization are not exact opposites. A city can be specialized if it has a sector with many times its national share of employment; it can, at the same time, be diversified if the rest of its employment mimics the national distribution of employment across sectors.

25. See the large literature initiated by Harris and Todaro (1970). See also Lall et al. (2006) and Duranton (2008) for critical assessments and discussions of policy misunderstandings of the HarrisTodaro framework. 
26. Although there is a long tradition of evaluation of such programs in the literature, this recent wave of work is methodologically much sounder than earlier work. Most importantly, these recent studies are able to find more meaningful control groups to control for the endogeneity of the treatment. They are also able to work with the high level of spatial resolution that those studies require.

27. This does not imply that every aspect of labor market regulation should be uniform. The minimum wage, for instance, could differ across cities to reflect differences in productivity and in the cost of living.

28. This is not to say, of course, that issues surrounding residential squatting are perfectly understood. Parallel to the work cited above, recent works have investigated the political economy of squatting in developing cities (Feler and Henderson 2011) and modelled the micro-functioning of squatter settlements and eviction (Brueckner and Selod 2009).

29. The urban literature often considers a nominal measure of market access (city income weighted by inverse distance). Theoretical models highlight that what should matter is the 'real market access', which accounts for the price indices in each location. A large city nearby may not be an attractive market for local producers if the prices in that city are low. Unfortunately, local prices are unobserved. The trade literature has developed a number of ways to circumvent this problem (Redding and Venables 2004; Head and Mayer 2004).

30. Duranton and Turner (2012) estimate a 20-year elasticity of city population with respect to highway kilometers of approximately 0.15 . Such an elasticity is enough to make roads a major determinant of urban growth, as suggested by most theoretical models of cities. However, in terms of costbenefit analysis, this elasticity is low when one wants to justify the constructions of more highways in US metropolitan areas.

31. What distinguishes this recent wave of work on the effects of infrastructure relative to previous work is its attention to identification issues. Regressing an urban outcome, such as suburbanization in the case of Baum-Snow (2007), on the presence of highways may fall foul of the fact that both variables are simultaneously determined. For instance, highways may have been built to accompany the movement of downtown residents to the suburbs. To solve this problem, Baum-Snow (2007) develops an ingenious instrumental variable strategy that rests on the fact that US highways were originally planned for a set of different purposes. This type of strategy is further developed by Duranton and Turner (2012) who look at urban growth in the US.

32. Baum-Snow et al. (2013) also examine roads and confirm for China the findings of BaumSnow (2007) regarding the importance of roads for residential decentralization. They find no effect of roads on the location of manufacturing activity, which may not be surprising given the reliance of Chinese manufacturing on rail. Banerjee, Duflo, and Qian (2009) provide further evidence about the effect of transportation on the development of China. See also Faber (2013).

\section{References}

Aarland, K., J. C. Davis, J. V. Henderson, and Y. Ono. 2007. "Spatial Organization of Firms: The Decision to Split Production and Administration." Rand Journal of Economics 38 (2) : 480-94.

Acemoglu, D., P. Aghion, and F. Zilibotti. 2006. "Distance to Frontier, Selection, and Economic Growth." Journal of the European Economic Association 4 (1) : 37-74.

Ades, A. F., and E. L. Glaeser. 1995. "Trade and Circuses: Explaining Urban Giants.” Quarterly Journal of Economics 110 (1) : 195-227.

Amiti, M., and L. Cameron. 2007. "Economic Geography and Wages." Review of Economics and Statistics 89 (1) : 15-29.

Audretsch, D. B., and M. P. Feldman. 1996. "R\&D Spillovers and the Geography of Innovation and Production." American Economic Review 86 (3) : 630-40. 
Bacolod, M., B. S. Blum, and W. C. Strange. 2009. "Skills in the City." Journal of Urban Economics 65 (2) : $136-53$.

Banerjee, A., E. Duflo, and N. Qian. 2009. "On the Road: Access to Transportation Infrastructure and Economic Growth in China.” Massachusetts Institute of Technology, Boston. Processed.

Bartelsman, E., J. Haltiwanger, and S. Scarpetta. 2004. "Microeconomic Evidence of Creative Destruction in Industrial and Developing Countries." University of Maryland, College Park, MD. Processed.

2013. "Cross-country Differences in Productivity: The Role of Allocation and Selection." American Economic Review 103 (1) : 305-34.

Baum-Snow, N. 2007. "Did Highways Cause Suburbanization?” Quarterly Journal of Economics 122 (2) : $775-805$.

Baum-Snow, N., L. Brandt, J. V. Henderson, M. A. Turner, and Q. Zhang. 2013. "Roads, Railways and Decentralization of Chinese Cities.” Brown University, Providence, RI. Processed.

Baum-Snow, N., and R. Pavan. 2012. "Understanding the City Size Wage Gap.” Review of Economic Studies 79 (1) : 88-127.

Behrens, K., G. Duranton, and F. Robert-Nicoud. 2014. "Productive Cities: Sorting, Selection, and Agglomeration." Journal of Political Economy 122 : (forthcoming).

Berry, C. R., and E. L. Glaeser. 2005. “The Divergence of Human Capital Levels across Cities.” Papers in Regional Science 84 (3) : 407-44.

Black, D., and J. V. Henderson. 2003. "Urban Evolution in the US.” Journal of Economic Geography 3 (4) : $343-72$.

Bosker, M., S. Brackman, H. Gerresten, and M. Schramm. 2012. "Relaxing Hukou. Increased Labor Mobility and China's Economic Geography”. Journal of Urban Economics 72 (1) : 252-66.

Brueckner, J. K., and H. Selod. 2009. "A Theory of Urban Squatting and Land-tenure Formalization in Developing Countries." American Economic Journal: Economic Policy 1 (1) : 28-51.

Brülhart, M., and F. Sbergami. 2009. "Agglomeration and Growth: Cross-country Evidence.” Journal of Urban Economics 65 (1) : 48-63.

Busso, M., J. Gregory, and P. Kline. 2013. "Assessing the Incidence and Efficiency of a Prominent Place Based Policy." American Economic Review 103 (2) : 897-947.

Carlino, G. A., S. Chatterjee, and R. M. Hunt. 2007. "Urban Density and the Rate of Invention." Journal of Urban Economics 61 (3) : 389-419.

Carlino, G., and R. Hunt. 2009. "What Explains the Quantity and Quality of Local Inventive Activity?" Brookings-Wharton Papers on Urban Affairs (1) : 65-123.

Chandra, A., and E. Thompson. 2000. "Does Public Infractsructure Affect Economic Activity? Evidence from the Rural Interstate Highway System." Regional Science and Urban Economics 30 (4) : $457-90$.

Charlot, S., and G. Duranton. 2004. "Communication Externalities in Cities." Journal of Urban Economics 56 (3) : 581-613.

Chauvin, J. P., E. L. Glaeser, and K. Tobio. 2013. "Urban Economics in the US and India." Harvard University, Cambridge, MA. Processed.

Chinitz, B. 1961. "Contrasts in Agglomeration: New York and Pittsburgh." American Economic Review Papers and Proceedings 51 (2): 279-89.

Ciccone, A., and R. E. Hall. 1996. "Productivity and the Density of Economic Activity." American Economic Review 86 (1) : 54-70.

Cingano, F., and F. Schivardi. 2004. "Identifying the Sources of Local Productivity Growth." Journal of the European Economic Association 2 (4) : 720-42. 
Combes, P.-P., G. Duranton, and L. Gobillon. 2008. "Spatial Wage Disparities: Sorting Matters!” Journal of Urban Economics 63 (2) : 723-42.

Combes, P.-P., S. Démurger, and L. Shi. 2013. "Urbanisation and Migration Externalities in China." Aix-Marseille School of Economics, Marseille. Processed.

2012a. "The Costs of Agglomeration: Land Prices in French Cities." Wharton School, University of Pennsylvania, Philadelphia. Processed.

Combes, P.-P., G. Duranton, L. Gobillon, D. Puga, and S. Roux. 2012b. "The Productivity Advantages of Large Cities: Distinguishing Agglomeration from Firm Selection." Econometrica 80 (6) : 2543-94.

Combes, P.-P., G. Duranton, L. Gobillon, and S. Roux. 2010. "Estimating Agglomeration Economies with History, Geology, and Worker Effects.” In E. L. Glaeser, ed., The Economics of Agglomeration. Cambridge, MA: National Bureau of Economic Research.

2012c. "Sorting and Local Wage and Skill Distributions in France." Regional Science and Urban Economics 42 (6) : 913-30.

Conley, T. G., F. Flyer, and G. R. Tsiang. 2003. "Spillover from Local Market Human Capital and Spatial Distribution of Productivity in Malaysia." Advances in Economic Analysis and Policy 3 (1) : Article 5.

Coulibaly, S., U. Deichmann, and S. V. Lall. 2007. "Urbanization and Productivity: Evidence from Turkish Provinces over the Period 1980-2000.” Policy Research Working Paper No. 4327. World Bank, Policy Research Department, Washington, DC.

Couture, V. 2013. "Valuing the Consumption Benefits of Urban Density." University of California, Berkeley. Processed.

Da Mata, D., U. Deichmann, J. V. Henderson, S. V. Lall, and H. G. Wang. 2007. "Determinants of City Growth in Brazil. Journal of Urban Economics 62 (2) : 252-72.

De la Roca, J., and D. Puga. 2012. “The Dynamic Earnings Premium of Dense Cities.” CEMFI, Madrid. Processed.

De Soto, H. 2000. The Mystery of Capital: Why Capitalism Triumphs in the West and Fails Everywhere Else. New York: Basic Books.

Deichmann, U., K. Kaiser, S. V. Lall, and Z. Shalizi. 2005. "Agglomeration, Transport, and Regional Development in Indonesia.” Policy Research Working Paper 3477. World Bank, Policy Research Department, Washington, DC.

Di Tella, R., S. Galliani, and E. Schargrodsky. 2007. "The Formation of Beliefs: Evidence from the Allocation of Land Titles to Squatters." Quarterly Journal of Economics 122 (1) : 209-41.

Donaldson, D. 2014. "Railroads of the Raj: Estimating the Impact of Transportation Infrastructure." American Economic Review (forthcoming).

Duranton, G. 2006. "Human Capital Externalities in Cities: Identification and Policy Issues.” In R. J. Arnott D. P. McMillen, eds., A Companion to Urban Economics. Oxford: Blackwell.

.2007. "Urban Evolutions: The Fast, the Slow, and the Still." American Economic Review 97 (1) : $197-221$.

Duranton, G. 2008. "Viewpoint: From Cities to Productivity and Growth in Developing Countries." Canadian Journal of Economics 41 (3) : 689-736.

. 2011. “California Dreamin': The Feeble Case for Cluster Policies.” Review of Economic Analysis $3(1): 3-45$.

. 2014a. "Agglomeration Effects in Colombia." Wharton School, University of Pennsylvania, Philadelphia. Processed.

2014b. "Roads and trade in Colombia" Wharton School, University of Pennsylvania, Philadelphia. Processed. 
Duranton, G., P. M. Morrow, and M. A. Turner. 2014. "Roads and Trade: Evidence from the US." Review of Economic Studies (forthcoming).

Duranton, G., and D. Puga. 2001. "Nursery Cities: Urban Diversity, Process Innovation, and the Life Cycle of Products." American Economic Review 91 (5) : 1454-77.

2004. "Micro-foundations of Urban Agglomeration Economies." In J. V. Henderson, and J.-F. Thisse, eds., Handbook of Regional and Urban Economics, volume 4. Amsterdam: NorthHolland.

2005. "From Sectoral to Functional Urban Specialisation." Journal of Urban Economics 57 (2) : $343-70$.

2013. "The Growth of Cities." In P. Aghion, and S. Durlauf, eds., Handbook of Economic Growth, volume 2. Amsterdam: North-Holland, forthcoming.

Duranton, G., and M. A. Turner. 2012. "Urban Growth and Transportation.” Review of Economic Studies 79 (4) : 1407-40.

Durlauf, S. N., P. A. Johnson, and J. W. Temple. 2005. "Growth Econometrics." In P. Aghion, and S. N. Durlauf, eds., Handbook of Economic Growth, volume 1A. Amsterdam: North-Holland.

Einiö, E., and H. G. Overman. 2011. "The Effects of Spatially Targeted Enterprise Initiatives: Evidence from UK Legi.” London School of Economics, London. Processed.

Ellison, G., E. L. Glaeser, and W. R. Kerr. 2010. "What Causes Industry Agglomeration? Evidence from Coagglomeration Patterns.” American Economic Review 100 (3) : 1195-213.

Eslava, M., J. Haltiwanger, A. Kugler, and M. Kugler. 2004. "The Effects of Structural Reforms on Productivity and Profitability Enhancing Reallocation: Evidence from Colombia." Journal of Development Economics 75 (2) : 333-71.

Faber, B. 2013. "Trade Integration, Market Size, and Industrialization: Evidence from China's National Trunk Highway System.” University of California, Berkeley. Processed.

Faberman, R. J. 2011. "The Relationship between Establishment Age Distribution and Urban Growth." Journal of Regional Science 51 (3) : 450-70.

Fay, M., and C. Opal. 1999. "Urbanization without Growth: A not-so-uncommon Phenomenon." Policy Research Working Paper 2412. World Bank, Policy Research Department, Washington, DC.

Feldman, M. P., and D. B. Audretsch. 1999. "Innovation in Cities: Science-based Diversity, Specialization and Localized Competition.” European Economic Review 43 (2) : 409-29.

Feler, L., and J. V. Henderson. 2011. "Exclusionary Policies in Urban Development: Under-servicing Migrant Households in Brazilian Cities." Journal of Urban Economics 69 (3) : 253-72.

Field, E. 2007. “Entitled to Work: Urban Property Rights and Labor Supply in Peru.” Quarterly Journal of Economics 122 (4) : 1561-602.

Figueiredo, O., P. Guimarães, and D. Woodward. 2002. "Home-field Advantage: Location Decisions of Portuguese Entrepreneurs." Journal of Urban Economics 52 (2) : 341-61.

Findeisen, S., and J. Südekum. 2008. "Industry Churning and the Evolution of Cities: Evidence for Germany." Journal of Urban Economics 64 (2) : 326-39.

Foster, L., J. C. Haltiwanger, and C. J. Krizan. 2001. "Aggregate Productivity Growth: Lessons from Microeconomic Evidence.” In C. R. Hulten, E. R. Dean, and M. J. Harper, eds., New Developments in Productivity Analysis. Chicago: National Bureau of Economic Research and University of Chicago Press.

Foster, L., J. Haltiwanger, and C. J. Krizan. 2006. "Market Selection, Reallocation and Restructuring in the U.S. Retail Trade Sector in the 1990s.” Review of Economics and Statistics 88 (4) : 748-58.

Foster, L., J. Haltiwanger, and C. Syverson. 2008. "Reallocation, Firm Turnover, and Efficiency: Selection on Productivity or Profitability?” American Economic Review 98 (1) : 394-425. 
Freedman, M. 2008. "Job Hopping, Earnings Dynamics, and Industrial Agglomeration in the Software Publishing Industry." Journal of Urban Economics 64 (3) : 590-600.

Fujita, M., and R. Ishii. 1998. "Global Location Behavior and Organizational Dynamics of Japanese Electronics Firms and their Impact on Regional Economies." In A. D. Chandler, Jr. P. Hagström, and Ö. Sölvell, eds., The Dynamic Firm: The Role of Technology, Strategy, Organization and Regions. Oxford: Oxford University Press.

Ghani, E., A. G. Goswami, and W. R. Kerr. 2012. "Highway to Success: The Impact of the Golden Quadrilateral Project for the Location and Performance of Indian Manufacturing." Working Paper 18524. National Bureau of Economic Research, New York.

Ghani, E., R. Kanbur, and S. O'Connell. 2013a. "Urbanization and Agglomeration Benefits. Gender Differentiated Impacts on Enterprise Creation in India's Informal Sector.” Policy Research Working Paper 6553. Policy Research Department, World Bank, Washington, DC.

Ghani, E., W. R. Kerr, and S. O'Connell. 2011. "Spatial Determinants of Entrepreneurship in India.” Harvard University, Cambridge, MA. Processed.

Ghani, E., W. R. Kerr, and I. Tewari. 2013b. "Specialization, Diversity, and Indian Manufacturing Growth." Harvard University, Cambridge, MA. Processed.

Glaeser, E. L. 1999. "Learning in Cities.” Journal of Urban Economics 46 (2) : 254-77. .2005. "Reinventing Boston: 1630-2003." Journal of Economic Geography 5 (2) : 119-53.

Glaeser, E. L., and J. D. Gottlieb. 2008. "The Economics of Place-making Policies.” Brookings Papers on Economic Activity (1) : 155-253.

Glaeser, E. L., H. Kallal, J. A. Scheinkman, and A. Shleifer. 1992. "Growth in Cities." Journal of Political Economy 100 (6) : 1126-52.

Glaeser, E. L., S. P. Kerr, and W. R. Kerr. 2012. "Entrepreneurship and Urban Growth: An Empirical Assessment with Historical Mines.” Harvard University, Cambridge, MA. Processed.

Glaeser, E. L., and W. R. Kerr. 2009. "Local Industrial Conditions and Entrepreneurship: How Much of the Spatial Distribution can we Explain?” Journal of Economics \& Management Strategy 18 (3) : 623-63.

Glaeser, E. L., W. R. Kerr, and G. A.M. Ponzetto. 2010. “Clusters of Entrepreneurship.” Journal of Urban Economics 67 (1) : 150-68.

Glaeser, E. L., and D. C. Maré. 2001. "Cities and Skills.” Journal of Labor Economics 19 (2) : 316-42.

Glaeser, E. L., and M. R. Resseger. 2010. "The Complementarity between Cities and Skills.” Journal of Regional Science 50 (1) : 221-44.

Gollin, D., R. Jedwab, and D. Vollrath. 2013. "Urbanization with and without Industrialization.” George Washington University, Washington, DC. Processed.

Greenstone, M., R. Hornbeck, and E. Moretti. 2010. "Identifying Agglomeration Spillovers: Evidence from Winners and Losers of Large Plants Openings.” Journal of Political Economy 118 (3) : 536-98.

Handbury, J. H., and D. E. Weinstein. 2010. "Is New Economic Geography Right? Evidence from Price Data." Columbia University, New York. Processed.

Harris, J. R., and M. P. Todaro. 1970. "Migration, Unemployment and Development: A Two-sector Analysis." American Economic Review 60 (1) : 126-42.

Head, K., and T. Mayer. 2004. "The Empirics of Agglomeration and Trade. In V. Henderson, and J.-F. Thisse, eds., Handbook of Regional and Urban Economics, volume 4. Amsterdam: NorthHolland.

Head, K., and T. Mayer. 2011. "Gravity, Market Potential and Development.” Journal of Economic Geography 11 (2) : 281-94. 
Henderson, J. V. 2005. "Urbanization and Growth.” In P. Aghion and S. N. Durlauf, eds., Handbook of Economic Growth, volume 1B. Amsterdam: North-Holland.

2010. "Cities and Development." Journal of Regional Science 50 (1) : 515-40.

Henderson, J. V., A. Kuncoro, and M. Turner. 1995. "Industrial Development in Cities." Journal of Political Economy 103 (5) : 1067-90.

Henderson, V. 2002. "Urbanization in Developing Countries." World Bank Research Observer 17 (1) : $89-112$.

2003. "The Urbanization Process and Economic Growth: The So-what Question.” Journal of Economic Growth 8 (1) : 47-71.

Henderson, V., T. Lee, and Y. J. Lee. 2001. "Scale Externalities in Korea." Journal of Urban Economics 49 (3) : 479-504.

Holl, A., and E. Viladecans-Marsal. 2011. "Infrastructure and Cities: The Impact of New Highways on Urban Growth.” Universitat de Barcelona, Barcelona. Processed.

Holmes, T. J. 1999. "Localisation of Industry and Vertical Disintegration." Review of Economics and Statistics 81 (2) : 314-25.

Hsieh, C.-T., and P. J. Klenow. 2009. "Misallocation and Manufacturing TFP in China and India." Quarterly Journal of Economics 124 (4) : 1403-48.

Jacobs, J. 1969. The Economy of Cities. New York: Random House.

Jaffe, A. B., M. Trajtenberg, and R. Henderson. 1993. "Geographic Localization of Knowledge Spillovers as Evidenced by Patent Citations.” Quarterly Journal of Economics 108 (3) : 577-98.

Jedwab, R. 2013. "Urbanization without Structural Transformation: Evidence from Consumption Cities in Africa." George Washington University, Washington, DC. Processed.

Jedwab, R., and A. Moradi. 2011. "Revolutionizing Transport: Modern Infrastructure, Agriculture and Development in Ghana." Sussex University, Brighton, UK. Processed.

Kerr, W. R. 2010. "Breakthrough Inventions and Migrating Clusters of Innovation.” Journal of Urban Economics 67 (1) : 46-60.

Kim, S. 2008. "Spatial Inequality and Economic Development: Theories, Facts, and Policies." In M. Spence, P. C. Annez, and R. M. Buckley, eds., Urbanization and Growth. Washington DC: World Bank.

Krugman, P. R. 1991. "Increasing Returns and Economic Geography." Journal of Political Economy 99 (3) : 484-99.

Krugman, P. R., and A. J. Venables. 1995. "Globalization and the Inequality of Nations." Quarterly Journal of Economics 110 (4) : 857-80.

Lall, S. V., R. Funderburg, and T. Yepes. 2004a. "Location, Concentration, and Performance of Economic Activity in Brazil.” Policy Research Working Paper 3268. World Bank, Policy Research Department, Washington, DC.

Lall, S. V., J. Koo, and S. Chakravorty. 2003. "Diversity Matters: The Economic Geography of Industry Location in India." Policy Research Working Paper 3072, World Bank, Policy Research Department, Washington, DC.

Lall, S. V., H. Selod, and Z. Shalizi. 2006. "Rural-urban Migration in Developing Countries: A Survey of Theoretical Predictions and Empirical Findings.” Policy Research Working Paper 3915. World Bank, Policy Research Department, Washington, DC.

Lall, S. V., Z. Shalizi, and U. Deichmann. 2004b. "Agglomeration Economies and Productivity in Indian Industry." Journal of Development Economics 73 (3) : 643-73.

Lin, J. 2011. "Technological Adaptation, Cities, and New Work." Review of Economics and Statistics $93(2): 554-74$. 
Liu, Z. 2007. "The External Returns to Education: Evidence from Chinese Cities." Journal of Urban Economics 61 (3) : 542-64.

Marshall, A. 1890. Principles of Economics. London: Macmillan.

Mayer, T., F. Mayneris, and L. Py. 2011. “The Impact of Urban Enterprise Zones on Firms' Location.” Science-Po, Paris. Processed.

Melo, P. C., D. J. Graham, and R. B. Noland. 2009. "A Meta-analysis of Estimates of Urban Agglomeration Economies." Regional Science and Urban Economics 39 (3) : 332-42.

Michaels, G. 2008. "The Effect of Trade on the Demand for Skill - Evidence from the Interstate Highway System.” Review of Economics and Statistics 90 (4) : 683-701.

Michaels, G., F. Rauch, and S. J. Redding. 2012. "Urbanization and Structural Transformation." Quarterly Journal of Economics 127 (2) : 535-86.

Michelacci, C., and O. Silva. 2007. "Why so Many Local Entrepreneurs?" Review of Economics and Statistics 89 (4) : 615-33.

Moretti, E. 2004. "Human Capital Externalities in Cities." In V. Henderson, and J.-E. Thisse, eds., Handbook of Regional and Urban Economics, volume 4. Amsterdam: North-Holland.

Muravyev, A. 2008. "Human Capital Externalities: Evidence from the Transition Economy of Russia." Economics of Transition 16 (3) : 415-43.

Neumark, D., and J. Kolko. 2010. "Do Enterprise Zones Create Jobs? Evidence from California's Enterprise Zone Program." Journal of Urban Economics 68 (1) : 1-19.

Nieto Galindo, V. M. 2007. "La aglomeración como una causa de la innovación en colombia." Planeación \& Desarrollo 38 (1) : 97-139.

Olley, G. S., and A. Pakes. 1996. "The Dynamics of Productivity in the Telecommunication Equipment Industry." Econometrica 64 (6) : 1263-97.

Overman, H. G., and D. Puga. 2010. "Labor Pooling as a Source of Agglomeration: An Empirical Investigation.” In E. L. Glaeser, ed., The Economics of Agglomeration. Cambridge, MA: National Bureau of Economic Research.

Overman, H. G., and A. J. Venables. 2005. "Cities in the Developing World." Report for the Department for International Development, London, UK.

Peri, G. 2002. "Young Workers, Learning, and Agglomerations." Journal of Urban Economics 52 (3) : $582-607$.

Porter, M. E. 1990. The Competitive Advantage of Nations. New York: Free Press.

Puga, D. 2010. "The Magnitude and Causes of Agglomeration Economies." Journal of Regional Science 50 (1) : 203-19.

Redding, S., and A. J. Venables. 2004. "Economic Geography and International Inequality.” Journal of International Economics 62 (1) : 63-82.

Rosenthal, S. S., and W. C. Strange. 2004. "Evidence on the Nature and Sources of Agglomeration Economies." In J. V. Henderson, and J.-F. Thisse, eds., Handbook of Regional and Urban Economics, volume 4. Amsterdam: North-Holland.

2010. "Small Establishments/Big Effects: Agglomeration, Industrial Organization and Entrepreneurship." In E. L. Glaeser, ed., The Economics of Agglomeration. Cambridge, MA: National Bureau of Economic Research.

Rothenberg, A. D. 2011. "Transport Infrastructure and Firm Location Choice in Equilibrium: Evidence from Indonesia's Highways.” University of California, Berkeley. Processed.

Saito, H., and M. Gopinath. 2011. "Knowledge Spillovers, Absortive Capacity, and Skill Intensity of Chilean Manufacturing Plants." Journal of Regional Science 51 (1) : 83-101. 
Shefer, D. 1973. "Localization Economies in SMAs: A Production Function Analysis." Journal of Urban Economics 13 (1) : 55-64.

Smith, A. 1776. An Inquiry into the Nature and Causes of the Wealth of Nations. London: Printed for W. Strahan and T. Cadell.

Storeygard, A. 2011. "Farther on Down the Road: Transport Costs, Trade and Urban growth in subSaharan Africa.” Tufts University, Medford, MA. Processed.

Sveikauskas, L. A. 1975. "The Productivity of Cities." Quarterly Journal of Economics 89 (3) : 393-413.

Wheeler, C. H. 2001. "Search, Sorting, and Urban Agglomeration.” Journal of Labor Economics 19 (4) : 879-99.

2006. "Cities and the Growth of Wages among Young Workers: Evidence from the NLSY." Journal of Urban Economics 60 (2) : 162-84.

2008. "Local Market Scale and the Pattern of Job Changes among Young Men." Regional Science and Urban Economics 38 (2) : 101-18.

Williamson, J. G. 1965. "Regional Inequality and the Process of National Development: A Description of the Patterns." Economic Development and Cultural Change 13 (4, part 2) : 1-84.

World Bank. 2009. World Development Report 2009: Reshaping Economic Geography. Washington DC: World Bank. 